Institute for Physical Chemistry. From 1949 onwards he was director of the Max.Planck Physicochemical Institute at Göttingen.

His first researches were in photochemistry, and the "Grundlagen der Photochemie" (1933), which he wrote with Harteck, is one of the best monographs on that subject. The most widely known example of his application of spectroscopy to physicochemica problems is his investigation of the thermal dissociation of water vapour into hydrogen molecules and hydroxyl radicals, the presence of which was detected and the concentration of which was determ ined spectrometrically. His estimate of $103.3 \mathrm{kcal}$ per mole as the energy of atomization of hydroxyl remains unchallenged after thirty years. Free radicals have long been recognized as intermediaries in gas reactions. It is one thing, however, to postulate their existence in order to derive a kinetic law or to explain the course of reaction, and quite another to demonstrate the existence and to measure the concentration of a specific free radical. Within recent years many experimentalists have decided to follow Bonhoeffer's example.

Bonhoeffer's most spectacular scientific achievement came in 1929, when he isolated para-hydrogen. This proved to be a crucial experiment, to be followed by rapid developments of the quantum theory of chemistry.

Eucken had in 1912 obtained highly anomalous rotational heat capacities for ordinary hydrogen gas, and Mecke in 1924 had recorded a curious alternation of intensities in the spectra of molecular hydrogen. The interpretation of these two apparently disconnected phenomena was given independently in 1927 by Dennison, Heisenberg and Hund, according to whom ordinary hydrogen, hitherto regarded as a pure substance, was in fact a $3: 1$ mixture of orthohydrogen and para-hydrogen, which differed from each other in their nuclear spins and in the rotational energy-levels accessible to them. Physical chemists, while not unimpressed by mathematical arguments based on symmetry properties of wave functions, remained, on the whole, sceptical, and would scarcely have accepted the quantal interpretation were hydrogen gas to remain an inseparable mixture. In 1929, Bonhoeffer and Harteck showed that at low temperatures in the presence of charcoal the conversion of ortho-hydrogen to para-hydrogen was almost complete. They obtained a sample which was 99.7 per cent pure para-hydrogen. Its vapour pressure at the triple point was found to be $2.1 \mathrm{~mm}$. higher than that of ordinary hydrogen and its boiling point $0.13^{\circ}$ lower. His pupils, A. and L. Farkas, showed that the ordinarily forbidden interconversion of ortho- and para-hydrogen could be effected catalytically by paramagnetic molecules or radicals or by atomic exchange, and the reaction $\mathrm{H}+p \cdot \mathrm{H}_{2}=$ $o . \mathrm{H}_{2}+\mathrm{H}$ has proved to be the simplest of known chemical changes, now understood to the last detail.

Bonhoeffer and his school at Frankfurt-am-Main were among the first in the field with experiments on pure deuterium. He was generous with the $9 \cdot 5 \cdot \mathrm{gm}$. sample of pure heavy water which his department had produced by the spring of 1934. Having schooled. his own team to be satisfied with $100 \mathrm{mgm}$. each, to be recovered after their micro-work, he lavishly sent 1-gm. samples all over the world. It was from him that Rutherford obtained his first sample.

By 1935 it was clear that Bonhoeffer's interests were moving slowly away from physical chemistry to biology ; papers appeared on deuterium in growing organisms, on the enzymic hydrolysis of glycosides in heavy water, and on the synthesis of polysaccharides in yeast cells. From 1941 onwards Bonhoeffer's principal experimental work dealt with membrane potentials and with the activation of passive iron as a physicochemical model of nerve excitation.

About half his publications appeared in the Zeitschrift für physikalische Chemie, of which he was editor with Bodenstein, Drucker and Simon from 1933 until his resignation in 1941. He was a founder editor of the new series of that journal which was issued in 1954 .

Despite his tribulations, K. F. Bonhoeffer preserved an essentially sunny disposition, sustained by a supremely happy home life with his wife, daughter and three sons. He could relax, forget chemistry, enjoy music, and dance well. In his work, he had the enthusiasm of a boy and a gift for inspiring young men. Above all, he was blessed with the humility which is the hall-mark of greatness.

E. A. Moelwyn-Hughes

\section{Dr. Otto Böhm}

By the death of Dr. Otto Böhm on May 17, at the age of seventy-two, the Royal Naval Scientific Service has lost a distinguished and devoted servant.

$\mathrm{He}$ was born at Zaborze in Upper Silesia on July 2,1884 , and graduated in power engineering at Berlin, proceeding later to his doctorate at Darmstadt with a thesis on the effects of transients in highvoltage power lines. Joining the Telefunken Co., where his interests moved towards electromagnetic theory and radio, he rose rapidly to become director of research in 1922. In these years he made a number of original contributions to research on radio aerials, among them being the 'Tannenbaum' element so frequently used as a component of broadside arrays for high-frequency communications. It was with the Telefunken Co., also, that he did pioneer work on the reflexion of radio waves from obstacles.

But he was a Jew, unobtrusively proud of the accomplishments of his ancient race and inimical to the rising tide of Nazi doctrine. When eventually he stood in peril, the Telefunken Co. gave him due warning and provided an escort to Switzerland.

In 1936 Böhm came to England, and in 1941 to H.M. Signal School (now Admiralty Signal and Radar Establishment). The first experimental $10-\mathrm{cm}$. radars were then being made in the laboratories for naval use, and there followed an intensely productive period in which he originated one micro-wave aerial after another. At this time his invention of the 'cheese' aerial, to give a fan-shaped beam, was outstandingly apposite to the ship-borne radar problem. This was all pioneer work in a new field of applied. science with no well-documented literature to show the way, and within a few weeks of their conception some of these aerials played vital parts in dramatic incidents both at sea and in coastal defence. To this work he brought a rare and remarkable combination of engineering design knowledge allied with an ability to go really deeply into the mathematical theory of aerial design.

His full-time service with the Establishment ended in 1946, but he continued as a consultant until his death, working as hard as ever and visiting the Establishment several times a month. His originality sparkled until the end, and in his last year he put forward a new approach to the problem of supergain 
arrays which is in the vanguard of thought on this subject.

Otto Böhm was a liberally educated man, versed in the German poets and philosophers, and as ready to talk on the more obseure works of Thomas Mann as he was to exercise his specialized science. Courteous and gentle by nature, and warm in friendship, he would make real personal sacrifices to help any colleague in adversity. As a groat teacher, he had an uncanny power for presenting difficult ideas in original and simple ways. It was a pleasure to watch him surrounded by four or five bright young scientists expounding some new idea, and to see him change his approach, or modify his argument, until he was quite sure all had understood. His face would then light up and the years seemed to fall away from him. Those enriched by these experiences, and all who sought him throughout the years, will feel the impact of Hilaire Belloc's lovely lines :

"He does not die that can bequeath Some influence to the land he knows"..-

for Otto Böhm loved Fngland, and has bequeather his influence abundantly. J. CRONEY

\section{NEWS and VIEWS}

\section{Extraction Metallurgy at the Imperial College : Prof. F. D. Richardson}

THF establishment of a second chair of motallurgy in the University of London omphasizes the growing, if tardy, recognition of the importance of this subject, and it is fitting that a chair of extraction metallurgy should be located in the Royal School of Mines, where this branch of the subject has always received considerable attention. Dr. F. D. Richardson, who has boen appointed to this chair, graduated in chemistry at University College, London, in 1933. After completing his postgraduate studios for the Ph.D. degree, he spent two years at the University of Princeton as a Commonwealth Fund fellow. At the outbreak of war in 1939, he was commissionod in the R.N.V.R. and his work on star shells during this period of service won for him an award from the Royal Commission on Awards to Inventors. Dr. Richardson's special interest in metallurgy commenced in 1946 when he was appointed superintendent chemist to the British Iron and Steel Research Association. During the next four years, while building up the Chemistry Department of that Association, he carried out theoretical and experimental investigations into the applications of thermodynamies to iron and steel making, work that has greatly increased our understanding of silicate melts and of the objects of slag control. As the result of these studies, the Sir George Beillby Memorial Award was conferred upon him in 1956, in recognition of his work on the thermodynamic properties of hightemperature systems, with special reforence to iron smelting and steelmaking.

On the establishment, through a generous grant from the Nuffield Foundation, of a Nuffield Research Fellowship in extraction metallurgy at the Royal School of Mines, Dr. Richardson was appointed as the first Nuffield Research fellow in 1950. In that capacity, and with valuable additional support from the metallurgical industry, he has been enabled to form the Nuffield Research Group which is engager in the extension of thermodynamic studies into the field of non-ferrous pyrometallurgy. Now that Dr. Richardson has been appointed to this new chair, it is to be expected that the investigations under his direction will be extended into the hydrometallurgical field that is of such growing importance. The eventual expansion of the metallurgy department, under the expansion scheme at the Imperial College of Science and 'Technology, should enable the Royal School of Minos to increase the supply of extraction metallurgists familiar with the modern trends in their profession and so enhance its reputation as the premier school in this branch of study.

\section{International Geophysical Year: Awards of the}

\section{Polar Medal}

THE following have been awarded the Polar Medal for good services as members of the advance party of the Royal Society Antarctic Expedition for the International Geophysical Year : Clasp to the Polar Medal, Surgeon Lieut.-Comdr. D. G. Dagliesh, R.N. (Sidcup), leader and medical officer; K. E. C. Powell (West Ewell), senior diesel mechanic ; Polar Medal, A. R. F. Dagliesh (Sideup), general duties; Dr. S. Evans (Stockport), scientist; Sgt. C. F. Le Feuvre, Royal Corps of Signals (Titton, Staffs), wireless operator; D. W. S. Limbert (Finchley), meteorologist; Lieut. G. R. Lush, R.N. (Cosham, Portsmouth), general mechanical engineer; D. R. O. Prior (Norwood), carpenter; J. E. Raymond (West Norwood), senior carpenter ; Major G. E. Watson, R.E.M.F. (Bromley, Kent), chief scientist.

The party were south of latitude $60^{\circ} \mathrm{S}$. from about December 28, 1955, to February 1, 1957. 'I he efforts of the expedition resulted in a notable acquisition of new knowledge of the meteorological conditions in that region, and, among other subjects, of the aurora australis and the habits of the Emperor Penguin.

\section{University of Reading}

Two publications, recently issued, show some aspects of the way the University of Reading is likely to develop. The first describes activities in the Museum of Rural Life during 1956 (Pp. 16. Reading : The University, 1957. 1s.) and contains details, not only of the exhibits, but also of three interesting exhibitions which were arranged at the Museum during the year. One of these was concerned with gardening in the eighteenth century, another with Welsh woodware and textiles, and the last with specialized forms of netting, lining and trapping used on the River Severn. The second publication (A History of Whiteknights. By Dr. Ernest Smith. Pp. iii +32 (4 plates). Reading: The University, 1957. $5 s .6 d$.) is a fine historical account of the origins and development of Whiteknights Park until its purchase by the University in 1947. With increasing pressure on land in this small island, this imaginative act may well lead to the University of Reading becoming one of the foremost residential universities in Great Britain. Both publications have been designed and produced with exquisite care and taste. 